\title{
SIGNIFIKANSI LABEL KEHORMATAN ISRAEL \\ DALAM 1 PETRUS 2:9-10 BERDASARKAN \\ TEORI IDENTITAS SOSIAL (SIT) *
}

\author{
Serepina Yoshika Hasibuan ${ }^{* *}$
}

\begin{abstract}
Abstrak: Topik mengenai pembentukan identitas sosial pembaca dalam surat 1 Petrus hangat diperbincangkan oleh para ahli. Dua monograf yang layak didiskusikan adalah karya Paul A. Himes dan David G. Horrell. Himes mengklaim bahwa foreknowledge Allah berperan dalam pembentukan identitas pembaca 1 Petrus (penelitian terhadap kata $\pi \rho o ́ \gamma \nu \omega \sigma \iota s$ dan

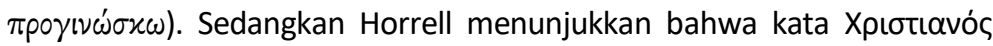
pada 4:16 berperan sebagai label yang membentuk identitas pembaca 1 Petrus. Berbeda dengan keduanya, penulis berpendapat bahwa Petrus membentuk identitas sosial pembacanya melalui kutipan Perjanjian Lama khususnya pada 1 Petrus 2:9-10. Masifnya penggunaan materi PL dalam 1 Petrus dan label kehormatan Israel yang diasosiasikan kepada pembaca menjadi pertimbangan dasar dari asumsi tersebut. Artikel ini akan menjelaskan bagaimana 1 Petrus 2:9-10 signifikan sebagai dasar pembentukan identitas sosial pembaca. SIT (Social Identity Theory) dipandang sebagai metodologi yang efektif untuk membuktikan hal tersebut. Teori dari Henri Tajfel ini mengklaim bahwa perilaku seseorang dipengaruhi oleh identitas sosialnya. Dalam perspektif ini, nasihat dalam 1 Petrus terkait erat dengan identitas sosial jemaat di mana perilaku jemaat diharapkan merefleksikan identitas sosialnya. Dari hasil penelitian ini terlihat bahwa kutipan Perjanjian Lama pada 2:9-10 berfungsi sebagai dasar pembentukan identitas sosial para pembaca surat ini yang menaikkan harga diri, menyatakan vokasi, menyatakan pengharapan yang
\end{abstract}

* Artikel ini ditulis sebagai ringkasan tesis program Magister Teologi yang telah diuji di Sekolah Tinggi Teologi Amanat Agung.

** Penulis adalah alumni Pascasarjana Sekolah Tinggi Teologi Amanat Agung dan melayani sebagai dosen di Sekolah Tinggi Teologi Mawar Saron Lampung. Penulis dapat dihubungi melalui email: serepinahasibuan1991@gmail.com 
terkandung dalam iman, dan membangun kekohesifan sebagai jemaat Kristus.

Kata kunci: 1 Petrus 2:9-10, Teori Identitas Sosial (SIT), pembentukan identitas sosial, Perjanjian Lama

\begin{abstract}
The formation of the social identity of the readers of 1 Peter is warmly discussed among scholars. Two monographs deserved mentioning are the works of Paul A. Himes and David G. Horrell. Based on research on $\pi \rho \gamma^{\gamma} \nu \omega \sigma \iota \varsigma$ and $\pi \rho \circ \gamma \iota \nu \omega \dot{\sigma} \kappa \omega$, the former claims that the foreknowledge of God contributes to the formation of the identity of 1 Peter's readers. The latter points that Xpıбıаvós in 4:16 functions as a label that forms the identity of 1 Peter readers. Different from these studies, the author argues that Peter builds the social identity of his readers through quotations of the Old Testament in 1 Peter 2:9-10. The massive use of the Old Testament in 1 Peter dan Israel's honorary labels associated with its readers support the assumption. This article demonstrates how 1 Peter 2:9-10 significantly functions as the foundation for the formation of the social identity of the readers. SIT (Social Identity Theory) is viewed as an effective methodology to prove the case. The theory of Henri Tajfel claims that one's behavior is influenced by his social identity. In this perspective, the exhortation in 1 Peter is closely connected with the social identity of the congregation as the behavior of the congregation should reflect its social identity. The present research shows that the Old Testament quotations in 2:9-10 function as basis for the formation of the social identity of its readers that elevate their self-esteem, express their vocation, explicate the hope in their faith, and establish their cohesion as the church of Christ.
\end{abstract}

Key words: 1 Peter 2:9-10; Social Identity Theory (SIT), formation of social identity, Old Testament

\title{
Pendahuluan
}

Pembentukan identitas sosial adalah topik yang masih hangat diperbincangkan oleh para ahli biblika, tetapi masih jarang 
dibahas untuk surat 1 Petrus. ${ }^{1}$ Menurut Paul A. Himes, identitas sosial pembaca 1 Petrus dibentuk berdasarkan pra-pengetahuan (foreknowledge) Allah. Tiga teks bukti yang diangkat adalah 1:2, 1:10-

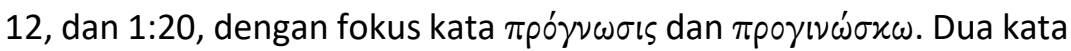
ini diartikan sebagai pra-pengetahuan Allah atau penentuan Allah sebelumnya mengenai jemaat. Dalam perspektif SIT, Allah memberikan pemahaman mengenai gambaran/identitas (sosial) umat-Nya. Sekalipun 1:10-12 merujuk pada PL, Himes tetap mengidentifikasi ayat tersebut sebagai bagian dari konsep prapengetahuan Allah, ${ }^{2}$ sehingga ia meyakini bahwa pra-pengetahuan Allah menjadi key role dalam pembentukan identitas sosial pembaca, ${ }^{3}$ yakni sebagai kata-kata penghiburan. ${ }^{4}$ Menurut penulis, ramalan PL pada 1:10-12 bukan merupakan bagian dari prapengetahuan Allah karena kata $\pi \rho o ́ \gamma \nu \omega \sigma \varsigma s ~ d a n ~ \pi \rho \circ \gamma \iota \nu \omega \sigma x \omega$ tidak terdapat dalam 1:10-12. Jadi, 1:10-12 tidak bisa dijadikan sebagai teks bukti untuk mendukung pra-pengetahuan Allah. Menurut penulis, justru 1:10-12 ini lebih tepat dijadikan bukti dasar untuk mendukung bahwa Petrus menjadikan PL sebagai bahan pembentuk identitas sosial pembaca.

Di sisi lain, David G. Horrell mengatakan bahwa pembentukan identitas sosial pembaca tampak pada pemberian

1. Paul A. Himes, Foreknowledge and Social Identity in 1 Peter (Eugene: Pickwick Publications, 2014), 3.

2. Himes, Foreknowledge and Social Identity in 1 Peter, 3.

3. Himes, Foreknowledge and Social Identity in 1 Peter, 182.

4. Himes, Foreknowledge and Social Identity in 1 Peter, 182. 


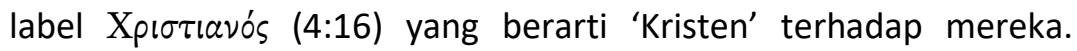

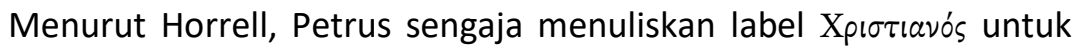
membalikkan nilai yang negatif menjadi positif. Akan tetapi, pada

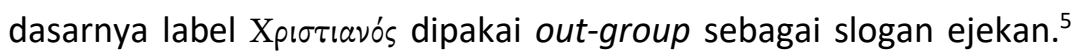

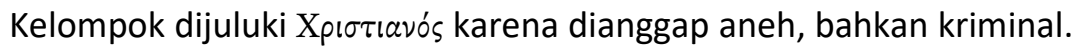
Memang Petrus tampak membela label tersebut dengan mengatakan bahwa justru melalui label itu mereka memuliakan Allah di dalam Yesus Kristus (4:16).

Akan tetapi menurut penulis, pembalikkan nilai label Xpıбıаvós tidak serta merta terjadi tanpa pemberian label yang lebih positif kepada pembaca. Secara psikologis, stigma negatif dari label tersebut sudah terlanjur teridentifikasi oleh pembaca. Itu sebabnya mereka malu. Pembaca sudah terbiasa dengan kesan negatif terhadap label tersebut. Dengan demikian, menurut penulis, label Xpıđıavós tidak cukup memadai untuk dipakai secara positif tanpa kehadiran label-label yang lain. Oleh karena itu, pemaknaan ulang label Xpıotıavós dilakukan dengan cara memberikan label lain untuk identitas sosial mereka yakni pada 2:9-10.

5. Judith N. Martin dan Thomas K. Nakayama, Intercultural Communication in Contexts, edisi keempat (New York: Mc Graw Hill, 2000), 165. Ada fase dimana kelompok minoritas lebih memilih untuk bertahan dengan status keminoritasan kelompoknya karena anggotanya benar-benar sadar bahwa nilai-nilai dalam kelompok mayoritas tidak sesuai dengan keyakinannya. 
Petrus memberikan label kehormatan Israel pada 2:9-10 untuk merekonstruksi ulang makna identitas sosial mereka. Status rendah yang diberikan oleh kelompok masyarakat di luar Kristen telah membentuk perspektif buruk tentang nilai diri para pembaca. Mereka malu menjadi Kristen. Oleh karena itu, Petrus perlu memberikan label-label kehormatan Israel, yakni "Bangsa Terpilih," "Imamat Rajani," “Bangsa yang kudus," "Umat Kepunyaan Allah," dan "Umat yang beroleh belas kasihan dari Allah." Keberadaan deretan label PL inilah yang memungkinkan pembaca untuk melihat label Xpıбıаvós secara lebih positif. ${ }^{6}$

Dalam perspektif SIT, deklarasi label kehormatan Israel memberi makna baru yang positif pada kelompok Kristen 1 Petrus. Petrus mendorong pembacanya untuk menilai diri secara positif sebelum menuntut pembaca untuk berlaku positif. Itu sebabnya, Petrus menuliskan deretan label tersebut pada bagian awal suratnya supaya nasihat surat lebih efektif tersampaikan dengan pemahaman diri yang benar. Tadinya mereka malu dengan identitas sosial mereka, tetapi asosiasi label Israel membuat mereka bangga

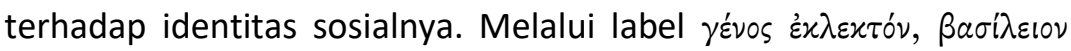

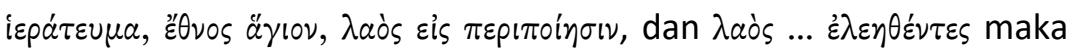

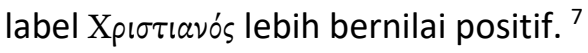

6. Bdk. Richard Jenkins, Social Identity, edisi keempat (Abingdon: Routledge, 2014), 97.

7. Trebilco menuliskan, "a label applied as an accusation, a cause for punishment and shame, is to be regarded as a badge of honor and pride." 
Fakta bahwa adanya pembentukan identitas sosial pembaca tampak dari deskripsi identitas berstatus jamak dengan beragam bentuk. Mulai dari pembukaan surat (1:1-2:10), berbagai deskripsi identitas pembaca ditulis baik dalam bentuk sapaan, idiom, maupun kutipan Perjanjian Lama. Berikut daftar identitas yang diberikan kepada pembaca.

\begin{tabular}{|c|c|c|c|}
\hline No. & Ayat & Bentuk & Identitas yang dituliskan \\
\hline 1. & 1:1 & Sapaan & $\begin{array}{l}\text { Orang-orang [terpilih] pendatang }{ }^{8} \text { yang } \\
\text { tersebar }\end{array}$ \\
\hline 2. & $1: 5$ & Sapaan & $\begin{array}{l}\text { [orang] yang dipelihara dalam kekuatan } \\
\text { Allah }\end{array}$ \\
\hline 3. & 1:14 & $\begin{array}{l}\text { perintah, } \\
\text { idiom }\end{array}$ & Anak-anak yang taat \\
\hline 4. & $1: 15-16$ & Perintah & Menjadi kudus \\
\hline 5. & $1: 23$ & Idiom & $\begin{array}{l}\text { Dilahirkan kembali dengan benih yang } \\
\text { tidak fana }\end{array}$ \\
\hline 6. & $2: 2$ & $\begin{array}{l}\text { perintah, } \\
\text { idiom }\end{array}$ & Bayi yang baru lahir \\
\hline 7. & $2: 5$ & $\begin{array}{l}\text { perintah, } \\
\text { idiom }\end{array}$ & Batu-batu hidup \\
\hline 8. & 2:9-10 & Kutipan & $\begin{array}{l}\text { bangsa yang terpilih, imamat yang rajani, } \\
\text { bangsa yang kudus, umat kepunyaan } \\
\text { Allah, umat Allah yang beroleh belas } \\
\text { kasihan }\end{array}$ \\
\hline 9. & $2: 11$ & Sapaan & $\begin{array}{l}\text { Saudara-saudaraku, pendatang dan } \\
\text { perantau }\end{array}$ \\
\hline 10. & $2: 17$ & Perintah & Orang-orang merdeka, hamba Allah \\
\hline
\end{tabular}

Bdk. Paul Trebilco, Self-designations and Group Identity in the New Testament (Cambridge: Cambridge University, 2014), 284.

8. Kata $\pi \alpha \rho \varepsilon \pi ı \delta n ́ \mu o เ \varsigma$ yang bermakna "transient strangers", "displaced persons" seolah memberikan gambaran rendah tentang kedudukan mereka di masyarakat. 


\begin{tabular}{|l|l|l|l|}
\hline 11. & $2: 18$ & Sapaan & Hamba-hamba \\
\hline 12. & $2: 24-25$ & Idiom & $\begin{array}{l}\text { Orang-orang yang sembuh; dahulu } \\
\text { seperti domba yang sesat }\end{array}$ \\
\hline 13. & $3: 1$ & Sapaan & Istri-istri \\
\hline 14. & $3: 5$ & Perintah & Perempuan-perempuan kudus \\
\hline 15. & $3: 7$ & Idiom & Teman pewaris \\
\hline 16. & $3: 12$ & $\begin{array}{l}\text { Kutipan } \\
\text { PL }\end{array}$ & Orang-orang benar \\
\hline 17. & $4: 12$ & Sapaan & Saudara-saudara yang kekasih \\
\hline 18. & $4: 16$ & Perintah & Orang Kristen \\
\hline 19. & $4: 18$ & Sapaan & Orang benar \\
\hline 20. & $5: 1$ & Sapaan & Para penatua \\
\hline 21. & $5: 2$ & Perintah & Kawanan domba Allah \\
\hline 22. & $5: 3$ & Perintah & Teladan \\
\hline 23. & $5: 5$ & Sapaan & Orang-orang muda \\
\hline 24. & $5: 13$ & Sapaan & Kawan yang terpilih \\
\hline
\end{tabular}

Dari berbagai deskripsi identitas di 1 Petrus, bagian 2:9-10 merupakan deskripsi terpanjang mengenai identitas pembaca yang disusun beruntut dari label-label kehormatan Israel dalam $\mathrm{PL}^{9}$ bahkan menjadi satu-satunya ayat PB yang merangkai identitas PL dengan mengutip lima identitas sekaligus dalam satu sapaan. Oleh karena itu, tidak berlebihan apabila mengatakan puncak pembentukan identitas sosial pembaca terjadi pada 1 Petrus 2:9-10 dan 1 Petrus 2:9-10 layak menjadi teks representatif untuk

9. Identitas tidak hanya digambarkan melalui $\mathrm{PL}$, misalnya identitas Xpıotıavóc. Identitas ini berkaitan erat dengan label PL dalam 1 Petrus 2:910. Bdk. David G. Horrell, "The label Xpıбıаvós: 1 Peter 4:16 and the Formation of Christian Identity," Journal of Biblical Literature, Volume 126 no. 2 (Desember: 2007), 361-81; Trebilco, Self-designations and Group Identity in the New Testament, 3; Scott McKnight, 1 Peter, The NIV Application Commentary (Grand Rapids: Zondervan, 1996), 110. 
memahami signifikansi pembentukan identitas sosial pembaca 1 Petrus berdasarkan kacamata SIT.

\section{Identitas Sosial dan SIT}

Identitas sosial, menurut Lim yang mengutip Jenkins, diartikan sebagai, "our understanding of who we are and of who other people are, and reciprocally, other people's understanding of themselves and of others (which includes us)."10 Identitas sosial dapat dimengerti sebagai bagian dari konsep diri individu ${ }^{11}$ yang dibangun dari keanggotaannya dalam kelompok sosial tertentu. ${ }^{12}$ Biasanya

10. Kar Yong Lim, Metaphor and Social Identity Formation in Paul's Letters to the Corinthians (Eugene: Pickwick Publishing, 2017), 31.

11. Setiap individu mempunyai identitas personal dan identitas sosial dalam dirinya. Identitas personal mendapatkan pemahaman diri dari konsep yang dibangun di dalam dirinya sendiri berdasarkan relasi antar individu. Identitas personal bersifat intim, bebas, langsung dan mewakili aspek-aspek esensial dan krusial dari diri individu. Sebaliknya, pemahaman diri dalam identitas sosial diperoleh dari keanggotaannya di suatu kelompok sosial. Dalam identitas sosial, gambaran diri seseorang tidak lagi bebas atau independen, melainkan bergantung pada gambaran identitas kelompok sosialnya. Ketidakbebasan yang dimaksudkan dalam identitas sosial bukan berarti individu tidak mempunyai hak untuk menentukan 'menjadi seperti apa' dirinya karena "desire for group membership is the desire to be recognized as an independent, unique individual." Selama individu mengasosiasikan dirinya dalam kelompok tertentu, maka ada pembatasan untuk mengekspresikan dirinya agar tetap sesuai kelompoknya. Stephen Worchel, "A Developmental View of the Search for Group Identity," dalam Social Identity: International Perspectives, ed. Stephen Worchel, J. Franscisco Morales, Dario Paez dan Jean-Claude Deschamps (London: Sage Publications, 1998), 55; Afthonul Afif, Teori Identitas Sosial (Yogyakarta: UII, 2015), 14.

12. Shelley E. Taylor, Letitia Anne Peplau dan David O. Sears, Psikologi Sosial, edisi dua belas (Jakarta: Kencana, 2009), 233; Bdk. Jhon P. Hewitt, Self and Society: A Symbolic Interactionist Social Psychology 
setiap individu memiliki lebih dari satu kategori kelompok yang akan membentuk identitas sosialnya, tetapi tidak mungkin mempunyai dua kategori sosial yang saling eksklusif. ${ }^{13}$

Meski identitas ini diturunkan dari keanggotaan suatu kelompok, tetapi identitas sosial bukan merupakan atribut kelompok, melainkan atribut dari diri seorang individu sebagai anggota kelompok. ${ }^{14}$ Identitas sosial dalam diri individu akan bergabung dengan identitas sosial dari individu-individu lain yang memiliki persamaan dengan dirinya. Kemudian gabungan identitas sosial tersebut membentuk jati diri suatu kelompok. Semua klaim berdasarkan penelitian mengenai identitas sosial melahirkan sebuah teori mengenai identitas sosial.

Teori Identitas Sosial (SIT) merupakan salah satu teori dalam ilmu psikologi sosial ${ }^{15}$ yang membuktikan keberadaan identitas sosial

(Massachusetts: Allyn and Bacon, 1994), 111; Tucker mengutip Tajfel dengan mendefinisikan kelompok sosial sebagai, "a collection of individuals who perceive themselves to be members of the same social category [and] share emotional involvement in this common definition of themselves." J. Brian Tucker, You Belong to Christ: Paul and Formation of Social Identity in 1 Corinthians 1-4 (Eugene: Pickwick Publications: 2010), 43.

13. Identitas yang saling eksklusif artinya dua identitas yang disanding individu berada dalam kategori yang sama. Misalnya, satu individu tidak mungkin memiliki identitas bangsawan sekaligus rakyat jelata dalam dirinya karena bangsawan dan rakyat jelata adalah sama-sama kategori strata sosial.

14. Philip F. Esler, "An Outline of Social Identity Theory" dalam $T \& T$ Clark Handbook to Social Identity in the New Testament (London: Bloomsbury T\&T Clark, 2016), 19.

15. Taylor, Peplau dan Sears, Psikologi Sosial, 36; Psikologi sosial sebagai ilmu pengetahuan yang berusaha memahami asal usul dan sebab terjadinya perilaku dan pemikiran individual dalam konteks situasi sosial. 
dalam diri seseorang. Henri Tajfel adalah pelopor teori ini. Fokus penelitian dari SIT adalah memahami perilaku kelompok sosial yang diteliti. Teori ini berisi tentang perspektif konseptual mengenai proses dan hubungan antar kelompok yang setiap individu perlu mengikuti suatu kelompok sosialnya (kebalikan dari analisis perilaku individualistik). Menurut teori ini, suatu kelompok sosial memengaruhi pembentukan konsep diri dan harga diri individu yang menjadi anggotanya. Setiap individu yang menyadari akan identitas sosialnya dalam suatu kelompok tertentu akan melakukan perilaku yang sesuai dengan norma kelompok tersebut. Setiap anggota melakukan norma kelompok secara bersamaan akan membentuk prototype (perilaku yang mirip) satu dengan lainnya. Hal inilah yang menjadi identifikasi kelompok. Kesimpulannya, jati diri kelompok dapat terlihat dari bagaimana perilaku kelompok dan bagaimana penilaian in-group (kelompok dalam) maupun out-group (kelompok luar) yang mengamati kelompok tersebut.

Dalam penelitian yang menggunakan lensa SIT ini, jemaat Kristen mula-mula yang membaca surat 1 Petrus dikategorikan sebagai suatu kelompok sosial, yakni kelompok Kristen di Asia Kecil (in-group), sedangkan masyarakat bukan Kristen dikategorikan sebagai kelompok luar (out-group). ${ }^{16}$ Sehubungan dengan perspektif

Robert A. Baron dan Donn Byrne, Psikologi Sosial, edisi sepuluh (Jakarta: Erlangga, 2003), 5.

16. Meskipun tidak lagi aktual dalam kehidupan masa kini, penelitian mengenai identitas sosial mereka masih berlaku karena ada bukti catatan sejarah yang menunjukkan pendeklarasian label secara lugas dalam surat 1 Petrus. Andrew D. Clarke dan J. Brian Tucker, "Social History and 
psikologi sosial yang dipakai dalam penelitian ini, maka untuk memahami 1 Petrus 2:9-10 dengan baik diperlukan konteks sosial penulisan surat 1 Petrus. Berikut penjabarannya.

\section{Kondisi Sosial Pembaca 1 Petrus}

Meski banyak ahli yang menganggap surat 1 Petrus adalah pseudonymous, ${ }^{17}$ tetapi beberapa bukti kuat menunjukkan bahwa Petrus merupakan penulis dari surat ini. ${ }^{18}$ la menuliskan suratnya di Roma, bukan Babilonia. ${ }^{19}$ Kata Babylon $(5: 13)$ harus dimaknai secara

Social Theory in the Study of Social Identity," dalam T\&T Clark Handbook to Social Identity in the New Testament, ed. J. Brian Tucker dan Coleman A. Baker (London: Bloomsbury, 2014), 44-45.

17. Paul J. Achtemeier, 1 Peter. Hermeneia (Minneapolis: Fortress, 1996), 2. Lihat juga komentar Eugene Boring tentang isu ini. Para scholar kontemporer mengklaim bahwa 1 Petrus ditulis oleh seorang murid yang menyembunyikan nama aslinya dan memakai nama Petrus dalam suratnya. 1 Petrus merupakan dokumen pseudophigrafa dari generasi kedua. M. Eugene Boring, 1 Peter, Abingdon New Testament Commentaries (Nashville: Abingdon, 1999), 30. Bahkan Perkins menyebutkan kemungkinan ada kelompok missionaris (Petrine group) yang Elliott namakan sebagai Petrine group yang bertugas mengedarkan surat ini. Pheme Perkins, First and Second Peter, James and Jude, Interpretation (Louisville: John Knox, 1995), 12; John H. Elliott, 1 Peter. The Anchor Bible (New York: Doubleday, 2000), 127; Karen H. Jobes, 1 Peter. BECNT (Grand Rapids: Baker Academic, 2005), 19.

18. Beberapa bukti yang diajukan antara lain: paralelisme beberapa teks dalam 1 Petrus dengan perkataan Petrus di Kitab Kisah Para rasul (1Pet. 1:10 dengan Kis. 2:16; 1Pet. 1:20 dengan Kis. 2:17; 1Pet. 1:20 dengan Kis. 2:23, 1Pet. 1:21 dengan Kis. 2:32-36), penekanan doktrinal yang berbeda dengan Paulus, Petrus mampu dwibahasa dan bahasa Yunani dan gaya penulisannya unik. Donald Guthrie, Pengantar Penjanjian Baru, terj. Hendry Ongkowidjojo, volume 3 (Surabaya: Momentum, 2009), 121; P.H.R. Houwelingen, Surat 1 Petrus (Surabaya: Momentum, 2018), 11-12.

19. Peter Davids, A Theology of James, Peter and Jude (Grand Rapids: Zondervan, 2014), 120. Informasi dari tradisi awal mengatakan 
kriptogram, seperti dalam kitab Wahyu (Why. 16:19; 17:5; 18:2). Sebagaimana diketahui bahwa surat ini merupakan surat edaran yang penyebarannya sangat luas, maka surat ini rentan untuk jatuh ke pihak yang salah. Oleh karena itu, pemakaian simbol Babylon ini merupakan strategi bijak untuk mengantisipasi apabila surat jatuh ke tangan pemerintah Romawi.

Informasi penting yang berkenaan dengan kondisi sosial penulisan surat adalah mengenai siapa penerima surat ini. ${ }^{20}$ Tertera dalam surat bahwa mereka ialah jemaat di lima provinsi yang disebutkan, yakni jemaat di Pontus, Galatia, Kapadokia, Asia ${ }^{21}$ dan Bitinia (1:1). ${ }^{22}$ Pada awalnya surat ditujukan kepada jemaat diaspora

bahwa pusat pelayanan Petrus di Barat bukan di Timur dan tidak ada bukti kuat bahwa ia pernah melayani di Timur. Selain itu, Petrus mati sebagai martir di kota Roma sehingga tidak masuk akal apabila sesaat sebelum kematiannya ia berada di Babylon Mesopotamia untuk menuliskan surat ini. F.F. Bruce, Peter, Stephen, James \& John (Grand Rapids: Eermand, 1979), 46; Guthrie, Pengantar Perjanjian Baru, 117.

20. Guthrie, Pengantar Perjanjian Baru, 117; Greg W. Forbes dan Jason J. F. Lim. 1 Peter. Farrer Road: Asia Theological Association, 2006, 11; Edmund Clowney, The Message of 1 Peter. The Bible Speaks Today (Nottingham: InterVarsity, 1988), 23; Boring, 1 Peter, 38; Wayne Grudem, 1 Peter (Grand Rapids: InterVarsity, 1988), 33; J.N.D. Kelly, A Commentary on the Epistle of Peter and Jude (Grand Rapids: Baker Book House, 1969), 33; Thomas R. Schreiner, 1, 2 Peter-Jude, NAC (Nashville: Broadman \& Holman, 2003), 36.

21. Terjemahan Baru LAI menyebutkan Asia Kecil, tetapi dalam teks Bahasa Yunaninya tertulis Asia.

22. Lima provinsi tersebut merupakan wilayah Asia Kecil yang terletak di bagian utara dari pegunungan Taurus. Dalam bukunya Michaels mencatat bahwa luas wilayah kelima provinsi tersebut sekitar 300.000 mil. Artinya, surat 1 Petrus tersebar sangat luas pada waktu itu. Michaels J. Ramsey, 1 Peter, WBC (Nashville: Thomas Nelson, 1988), 44. Dalam masa 
yang ada di perantauan, yakni jemaat beretnis campuran dengan mayoritas jemaat kelompok etnis bukan Yahudi. ${ }^{23}$ Mereka berada di wilayah Asia Kecil. ${ }^{24}$

Secara geografis, situasi sosial dalam masyarakat Yahudi di Asia Kecil seharusnya lebih kondusif daripada situasi di Roma. Setidaknya hal ini berlaku bagi mereka yang telah dideportasi dari kota Roma ke daerah-daerah diaspora jajahan Roma. Mereka tidak mengalami situasi sesulit ketika mereka berada di Roma, ${ }^{25}$ karena tekanan politik dan religius di Roma relatif lebih besar. Namun demikian, beradaptasi di lingkungan baru sebagai tempat pengungsian tidaklah mudah bagi mereka. Status minoritas, perantau, dan Kristen yang disandingkan tentu memberi tekanan sosial dalam diri jemaat Kristen Yahudi. Sedangkan bagi jemaat

modern, lima provinsi ini termasuk wilayah Turki. Clowney, The Message of 1 Peter, 16.

23. Forbes dan Lim, 1 Peter, 8; Davids, A theology of James, Peter, and Jude, 103; Schreiner, 1, 2 Peter, Jude, 38. Paul Gardner, 1 \& 2 Peter \& Jude: Christian Living in An Age of Suffering (Ross-Shire: Christian Focus, 2001), 13. Kesimpulan bahwa jemaat didominasi oleh umat yang berlatar belakang bukan Yahudi berdasarkan pada ketajaman beberapa nasihat surat yang menggambarkan masa lalu mereka $(1: 14,18)$ dan tipe nasihat Housecode yang mirip dengan budaya Yunani.

24. D.A. Carson, "1 Peter" dalam Commentary on the New Testament of the Old Testament, ed. G.K. Beale dan D.A. Carson (Grand Rapids: Baker Academic, 2007), 1016; Howard Clark Kee, The Beginnings of Christianity (New York: T\&T Clark, 2005), 318.

25. Carson menambahkan bahwa di zaman pemerintahan Claudius, terjadi relokasi penduduk ke lima provinsi yang disebutkan di surat yang merupakan daerah rekolonialisasi Roma. Mereka dipindahkan oleh pemerintah sehingga mereka merasa seperti generasi buangan di tanah yang asing. Carson, "1 Peter," 1016. 
Greco-Roman yang menjadi Kristen (sekalipun mereka sudah lama menjadi warga setempat dan mempunyai hak penuh sebagai warga Roma), status sebagai orang Kristen membuat situasi mereka mirip seperti seorang pengungsi. ${ }^{26}$ Mereka tidak lagi mempunyai akar dalam komunitas mereka mula-mula yang menyembah berhala. ${ }^{27}$ Status religius yang baru membuat mereka benar-benar terpisah dengan masyarakat penyembah berhala yang lain. ${ }^{28}$ Jadi, pada dasarnya baik jemaat Kristen Yahudi maupun bukan Yahudi samasama pada posisi sebagai orang asing.

Status sebagai orang asing ini tampak jelas menggambarkan bahwa situasi sosial di dalam jemaat tidak kondusif, bahkan secara eksplisit dituliskan bahwa jemaat mengalami penderitaan yang besar. ${ }^{29}$ Penderitaan yang mereka alami sebagian besar disebabkan dari fitnahan masyarakat penyembah berhala yang tidak suka dengan ritual Kekristenan di sana. Tidak hanya fitnahan yang bersifat verbal, Horrell mengatakan sangat mungkin mereka juga mengalami penderitaan fisik. ${ }^{30} \mathrm{Hal}$ yang pasti adalah surat ini ditulis sebelum

26. Houwelingen, Surat 1 Petrus, 39.

27. Houwelingen, Surat 1 Petrus, 39.

28. Orang-orang bukan Yahudi cenderung mengikuti budaya Yahudi Kristen (menjadi proselit) sehingga menimbulkan ketegangan dengan kerabat mereka. Kaum proselit ini meninggalkan keluarga dan teman-temannya demi kebaikan dan demi agama. Abraham J. Malherbe, Social Aspects of Early Christianity, edisi kedua (Philadelphia: Fortress, 1983), 51.

29. Brandon D. Crowe, The Message of the General Epistles in the History of Redemption (New Jersey: P\&R Publishing, 2015), 6.

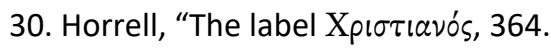


penganiayaan legal yang dilakukan pemerintahan Romawi kepada kaum Kristen di perantauan. ${ }^{31}$ Jadi penderitaan jemaat bersifat local, bukan global ${ }^{32}$ dan meskipun penekanan penderitaan di dalam surat berupa fitnahan dari lingkungan out-group tidak menutup kemungkinan mereka juga mengalami penderitaan fisik akibat iman yang mereka anut.

Fitnahan dari masyarakat bukan Kristen (kelompok luar) menimbulkan konflik eksternal dengan jemaat (kelompok dalam). Tidak ada indikasi yang membuktikan adanya konflik internal yang terjadi dalam jemaat. ${ }^{33}$ Jemaat bergumul dengan masyarakat penyembah berhala yang membenci agama Kristen. Orang-orang Kristen dianggap sebagai resident aliens dalam masyarakat. ${ }^{34}$ Mereka mengalami krisis identitas. Selain itu, keterpurukan semakin parah karena status ekonomi dan sosial mereka yang rendah di masyarakat. ${ }^{35}$ Jadi, dalam perspektif psikologi sosial, jemaat 1 Petrus

31. J.N.D. Kelly, A Commentary on the Epistle of Peter and Jude (Grand Rapids: Baker Book House, 1969), 5.

32. John. H. Elliott, Home for the Homeless (Philadelphia: Fortress, 1981), 80.

33. Houwelingen, Surat 1 Petrus, 3; Reinhard Feldmeier, The First Letter of Peter (Waco: Baylor University, 2008), 12.

34. I. Howard. Marshall, 1 Peter. The IVP New Testament Commentary Series (Illinois: InterVarsity, 1991), 24.

35. Dalam bukunya, Ferguson mencatat bahwa 1 dari 5 penduduk Roma adalah budak. Selain itu, menurut catatan kuno, budak diibaratkan sebagai living property atau articulate instrument, barang yang digunakan untuk membantu menjalani kehidupan dengan mudah. Mereka tidak mempunyai hak, bisa dijual ataupun dibuang. Apabila mereka diizinkan untuk menikah dengan sesama budak, anak mereka pun menjadi milik tuannya. Tuan berotoritas penuh terhadap budaknya. Everett Ferguson, 
adalah jemaat yang mempunyai nilai identitas sosial yang rendah. Hal inilah yang membuat mereka merasa malu menjadi Kristen. Menanggapi hal ini, Petrus mengasosiasikan label kehormatan Israel untuk mereka.

\section{Signifikansi Label Kehormatan Israel dalam Perjanjian Lama}

Label kehormatan Israel tidak sembarang dikutip oleh Petrus, sekalipun Petrus memaknai subjeknya lebih luas daripada konteks PL. Kelima label kehormatan yang tertulis di dalam PL jelas merujuk pada Israel sementara Petrus mengasosiasikan label tersebut kepada jemaat dengan latar belakang etnis yang beragam (Yahudi dan bukan Yahudi). Meskipun Petrus melakukan perluasan subjek, nyatanya ditemukan bahwa terdapat kesamaan signifikansi label baik untuk bangsa Israel di PL maupun untuk jemaat 1 Petrus di PB. Untuk melihat persamaan konteks keduanya, maka perlu terlebih dahulu meneliti signifikansi label kehormatan Israel dalam teks PL, baik di Keluaran, Yesaya, dan Hosea yang merupakan kitab tempat lima label tersebut berada. Oleh sebab itu, untuk memahami signifikansi label diperlukan penelusuran pada konteks originalnya.

Konteks Keluaran

Pasal 19-25 menjadi fokus utama dari kitab Keluaran, karena pada bagian ini dicatat tentang kisah umat Israel mengikat perjanjian

Backgrounds of Early Christianity. Edisi ketiga (Grand Rapids: Eermand, 2003), 59. 
dengan Yhwh di gunung Sinai. Kisah perjanjian diawali dengan pemberian proposal perjanjian dari Yhwh kepada umat Israel melalui Musa di Keluaran 19:1-6. Turunan dari proposal perjanjian ini adalah hukum-hukum yang perlu ditaati bangsa Israel di Keluaran 20:123:33. Akhirnya perjanjian antara Yhwh dan bangsa Israel dilakukan di 24:1-18. Fokus diskusi kita ada pada proposal perjanjian di Keluaran 19:3-6. Ayat tersebut berisi identitas perjanjian bangsa

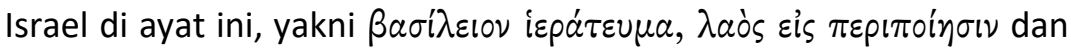
हैOvos ă $\gamma 10 \nu$ (Petrus mengutip dua identitas dari bagian ini). IdentitasIdentitas ini penting ditulis karena menggambarkan visi dan janji yang Yhwh akan penuhi dengan syarat bangsa ini setia dan taat kepadaNya.

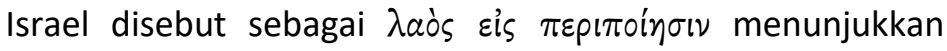
bahwa Israel akan menjadi umat milik Allah yang unik dan paling berharga di hati Yhwh. ${ }^{36}$ Identitas ini jelas menaikkan harkat/martabat bangsa Israel. Sebelumnya, di tanah Mesir mereka adalah kaum budak (kelas terendah) di dalam struktur masyarakat Ancient Near East. Sekarang, mereka telah menjadi bangsa yang bebas yang berharga di mata Yhwh. Identitas sebagai $\beta \alpha \sigma i \lambda \varepsilon \varepsilon$ เov

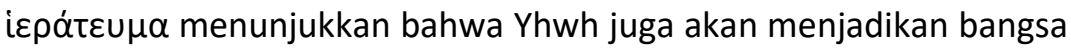
Israel sebagai alat-Nya untuk menyiarkan, membagikan dan memperluas kehadiran Allah di tengah dunia ini. "Kerajaan” tidak

36. Greek-English The Brill Dictionary of Ancient Greek, s.v. "лєрьои́бı૬." 
dimaksudkan untuk menunjukkan kekuasaan secara politik, tetapi status mereka sebagai para imam bagi Yhwh yang menjadi Raja mereka. Identitas ini jelas menekankan vokasi dari bangsa Israel. Status sebagai imam tidak hanya mendeskripsikan status terhormat, tetapi juga tugas Israel di hadapan Allah.

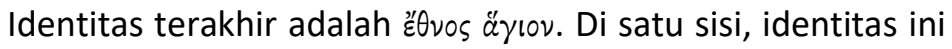

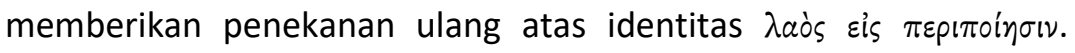
Mereka adalah bangsa yang dikhususkan bagi Yhwh. Di sisi lain, sebagai bangsa yang membangun hubungan perjanjian dengan Yhwh, Israel merefleksikan kekudusan Yhwh (Im. 19:1-2; bdk. 1Pet. 1:16) di dalam kehidupan mereka. Tidaklah mengherankan bahwa program untuk membangun kekudusan Israel ini terkoneksi erat dengan perintah di ayat 5, yakni setia kepada perjanjian Yhwh dan taat kepada semua perintah-perintah-Nya. ${ }^{37}$ Hanya dengan ketaatan, Israel dapat dibangun sebagai bangsa yang memancarkan kekudusan Yhwh.

\section{Konteks Yesaya}

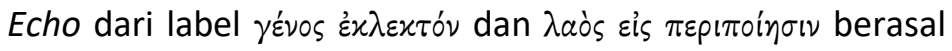
dari Yesaya 43:20-21. Para ahli sepakat bahwa Yesaya 40-55 menyampaikan pesan dari Yhwh, Allah Israel, kepada bangsa Israel yang berada di tanah pembuangan, Babel. Pada dasarnya berita yang disampaikan pada bagian ini adalah kabar baik dari Yhwh. Kabar baik

37. Terence E. Fretheim, Exodus. Interpretation (Louisville: John Knox, 1991), 216. 
ini tampaknya tidak serta merta disambut dengan sukacita, tetapi dengan kegalauan oleh umat Israel di tanah pembuangan (40:21). Ini disebabkan karena mereka menganggap diri sendiri sebagai bangsa yang kalah dan tidak berdaya. Bagi banyak orang Israel, Yhwh kalah berkuasa dibandingkan dewa-dewa orang Babel, sehingga mereka melakukan ritual kafir (2:6). Mereka menganggap Yhwh tidak sanggup membebaskan mereka dari cengkraman bangsa Babel (40:27). Bagi mereka, identitas sebagai umat Yhwh bukanlah hal yang dibanggakan, tetapi memalukan (40:9). Di hadapan bangsa lain, mereka mengidentifikasi diri mereka sebagai cacing, ulat (41:14), orang-orang tuli (42:18; 43:8), dan orang-orang buta (42:18). Di dalam konteks inilah pembangunan identitas bangsa Israel di Yesaya

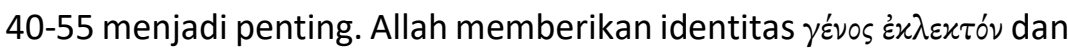
$\lambda$ aòs sis $\pi \varepsilon p \iota \pi$ oin $\sigma \iota \nu$ supaya bangsa Israel kembali menyadari identitas mereka yang sesungguhnya di hadapan Allah, sekalipun mereka mengalami pembuangan.

Konteks Hosea

Hosea pasal 1-3 berisikan berita tuduhan dan penghakiman Allah disampaikan kepada umat yang telah berpaling dari-Nya. Akan tetapi, berita penghakiman tersebut dilanjutkan dengan berita pengharapan. ${ }^{38}$ Model penyampaian nubuatan Hosea yang terbilang unik menggambarkan bagaimana relasi Allah dengan Israel. Israel

38. Gary V. Smith, Hosea, Amos, Micah, The NIV Application Commentary (Grand Rapids: Zondervan, 2001), 29. 
telah melawan Allah, tetapi Allah tidak meninggalkan mereka. Meskipun Israel rusak total karena ketidaksetiaan mereka, Israel masih merupakan harta kesayangan Allah. ${ }^{39}$ Allah sendiri yang akan merestorasi dan memperbaharui Israel di masa depan.

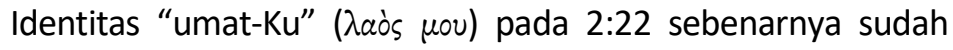
dituliskan pada pasal 1:6, 8 dan 9. Identitas ini merujuk pada Israel melalui penggambaran anak-anak Gomer. Konteks dekat menjelaskan adanya ketegangan antara Israel dengan Allah. 2:22 merupakan

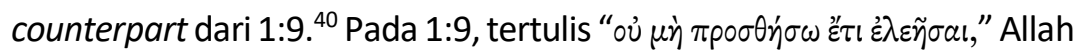
tidak akan memberikan belas kasihan kepada mereka, bahkan la

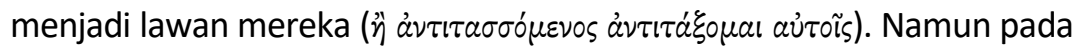
2:22-23, Allah dengan belas kasihan-Nya (LXX, 2:25) menerima kembali

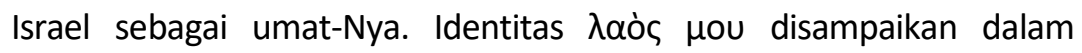
pembahasan mengenai penerimaan kembali Israel yang secara langsung dikaitkan dengan belas kasihan ' status Israel, identitas ini mengindikasikan pengharapan Israel di masa depan yang ideal. ${ }^{41}$

Dari berbagai konteks PL yang dijabarkan di atas, maka dapat disimpulkan ada tiga signifikansi identitas kehormatan Israel, yakni

39. Robert L. Hubbard Jr. dan Andrew Dearman, Introducing the Old Testament (Grand Rapids: Eerdmans, 2018), 344-45.

40. Francis Landy, Hosea. Edisi kedua (Sheffield: Sheffield Phoenix, 2011), 46.

41. Ehud Ben Zvi, Hosea, volume XXIA (Grand Rapids: Eerdmans, 2005), 76. 
pengangkatan martabat Israel, pemberian tugas/vokasi kepada Israel dan pemberian pengharapan untuk masa depan.

\section{Petrus 2:9-10 dalam Perspektif SIT}

1 Petrus 2:9-10 secara umum dipahami sebagai suatu kutipan yang lebih tepat disebut sebagai echo karena keunikan pengutipannya. Namun dalam perspektif SIT, 1 Petrus 2:9-10 memiliki nilai psikologis yang lebih daripada ayat lain yang berisikan identitas. 1 Petrus 2:9-10 berisi deretan identitas yang diringkas dan dikemas menjadi satu kesatuan yang panjang. Dalam perspektif SIT, label-label kehormatan Israel di 1 Petrus 2:9-10 ini menjadi puncak pembentukan identitas sosial pembaca. Aspek iman kepada Yesus Kristus membuat mereka terhubung satu dengan yang lain dalam satu kelompok.

Pembentukan identitas sosial jemaat 1 Petrus diperlukan karena mereka sedang mengalami krisis identitas yang membuat mereka merasa malu menjadi Kristen. Petrus mengasosiasikan label kehormatan Israel kepada mereka (sekalipun sebagian bukan merupakan keturunan Yahudi) untuk tujuan yang spesifik, yakni menyadarkan nilai diri jemaat sebagai umat Allah yang juga beroleh status yang sama di hadapan Allah. Krisis identitas membuat mereka menilai diri dengan rendah. Oleh karena itu, identitas kehormatan Israel merupakan hal yang signifikan untuk menyadarkan identitas rohani mereka.

Dengan demikian, dalam perspektif SIT, peran PL bukan sekadar menjadi referensi teologis untuk ajaran-ajaran Petrus dalam suratnya, 
tetapi juga bahan pembentuk identitas sosial pembaca khususnya menyangkut kutipan 1 Petrus 2:9-10.42

\section{Signifikansi label 1 Petrus 2:9-10 untuk Pembaca 1 Petrus}

Sebelum membahas signifikansi label kehormatan yang diasosiasikan oleh Petrus kepada jemaat 1 Petrus yang bukan seluruhnya orang Yahudi, perlu diketahui dahulu mengenai versi terjemahan apa yang digunakan Petrus dalam kutipan PL di suratnya dan dalam bentuk apa kutipannya. Berdasarkan penelitian yang dilakukan, tampaknya sangat mungkin Petrus menggunakan terjemahan Septuaginta. ${ }^{43}$ Perbandingan kutipan label yang ditulis Petrus dapat dipaparkan sebagai berikut:

\begin{tabular}{|c|c|c|}
\hline Lima Label Kehormatan & Septuaginta & 1 Petrus 2 \\
\hline Umat Terpilih & 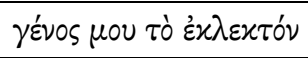 & 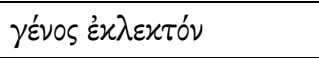 \\
\hline Imamat Rajani & 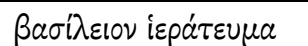 & 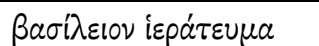 \\
\hline Bangsa yang Kudus & 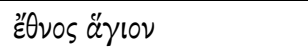 & 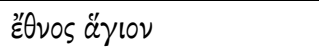 \\
\hline Umat kepunyaan Allah & 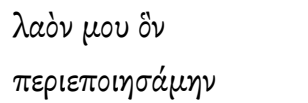 & 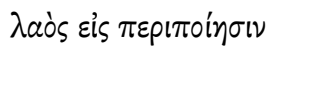 \\
\hline $\begin{array}{l}\text { Umat Allah yang } \\
\text { beroleh belas kasihan }\end{array}$ & 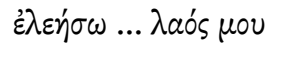 & 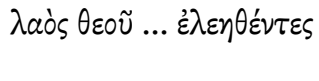 \\
\hline
\end{tabular}

42. James E. Cote dan Charles G. Levine, Identity Formation, Agency and Culture: A Social Psycological Synthesis (New Jersey: Lawrence Erlbaum Associates, 2002), 15.

43. Petrus menggunakan terjemahan Septuaginta untuk pengutipan teks PL di dalam suratnya. Hal ini didukung oleh dua alasan dasar. Pertama, penduduk diaspora di Asia Kecil berbahasa Yunani yang tentunya menggunakan kitab suci PL berbahasa Yunani, yaitu terjemahan Septuaginta. Kedua, terdapat penggunaan kata-kata yang hampir identik antara 1 Petrus 2: 9-10 dengan teks PL yakni Keluaran 19: 5-6, Yesaya 43: 20-21 dan Hosea 2:23, 25 versi LXX. Steve Moyise, The Old Testament in the New (London: Continuum, 2001), 109. 
Di dalam teks 1 Petrus memang ada beberapa identitas yang tampil identik dengan teks narasumbernya, seperti $\beta a \sigma i \lambda \varepsilon ı v$ iєрá $\tau \varepsilon u \mu a$

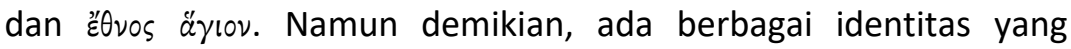
dimodifikasi oleh sang penulis sesuai dengan kebutuhan konteks

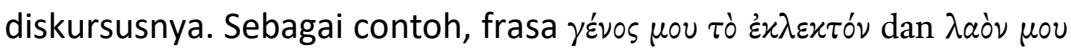

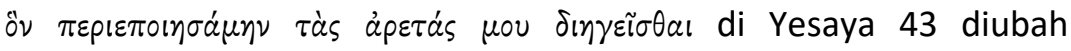

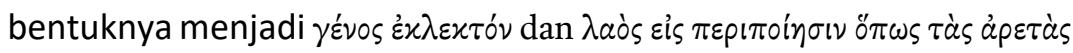

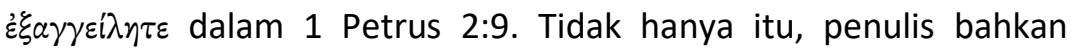

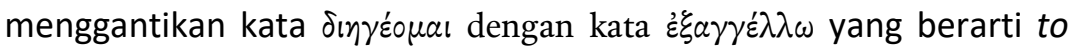
publish, adversite and to do so in the sense of telling something otherwise unknown. Hal ini dilakukan untuk menekankan aspek penginjilan kepada orang yang belum percaya. ${ }^{44}$ Akhirnya, penulis juga dengan leluasa merangkai ketiga teks PL (Yes. 45:20-21; Kel. 19:5-6; Hos. 2:23, 25) menjadi satu teks komposit yang dikehendaki. Dengan pertimbangan ini dapat disimpulkan bahwa pemakaian PL di dalam 1 Petrus 2:9-10 sebaiknya dikategorikan sebagai alusi / echo.

Sama seperti di dalam PL, echo identitas kehormatan Israel mempunyai signifikansi terhadap jemaat 1 Petrus. Berdasarkan penelitian yang dilakukan, terdapat kemiripan signifikansi identitas baik di PL maupun di 1 Petrus. Ada empat signifikansi identitas di dalam 1 Petrus yang akan dijabarkan satu per satu di bawah ini.

44. Jobes, 1 Peter, 159. 
Identitas 1 Petrus 2:9-10 Meningkatkan Harga Diri Pembaca

Identitas Kristen merupakan label ejekan untuk orang-orang yang menjadi pengikut Yesus Kristus, ${ }^{45}$ sehingga membuat harga diri mereka menjadi rendah. Dalam lensa SIT, identitas sebagai Kristen menjadi identitas aktual pembaca yang diterima oleh kelompok berdasarkan penilaian dari masyarakat luar. Identitas ini sangat memengaruhi kelompok menilai diri mereka. ${ }^{46}$ Dalam kondisi jemaat yang merasa identitasnya rendah, Petrus perlu membalikkan nilai identitas Kristen menjadi lebih positif. Hal ini dilakukan dengan cara mengadopsi label PL pada 1 Petrus 2:9-10. Jadi, dalam perspektif SIT, label PL pada 1 Petrus 2:9-10 merupakan deklarasi identitas virtual pembaca. ${ }^{47}$ Usaha ini sama dengan proses pelabelan. ${ }^{48}$ Melalui pelabelan, kelompok akan menyadari lebih jelas tentang identitas spiritual mereka, sehingga mereka mampu menolak identifikasi eksternal dari out-group. ${ }^{49}$

Label-label 1 Petrus 2:9-10 sengaja dideklarasikan secara beruntut dan powerful untuk menciptakan deviasi penilaian diri

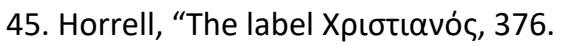

46. Horrell, "The label Xpıotıavós," 377.

47. Identitas virtual adalah identitas yang perlu dimunculkan dalam imajinasi kelompok mengenai keberadaan kelompok dalam sisi penilaian yang berbeda dan lebih positif. Meski bersifat imajinatif, identitas virtual tidak manipulatif karena identitas itu dibangun berdasarkan iman kepercayaan kelompok (spiritual). Jenkins, Social Identity, 99; Trebilco, Selfdesignations and Group Identity in the New, 284.

48. Pelabelan merupakan proses pemberian klaim atau klaim kontra (dengan lawan), sehingga identitas yang rendah dalam kenyataannya dapat menjadi lebih 'normal.' Jenkins, Social Identity, 99-100.

49. Bdk. Jobes, 1 Peter, 164. 
anggota kelompok. ${ }^{50}$ Kelompok Kristen akan memperoleh dan merasakan pengalaman baru yang lebih positif dari identitas tersebut. Masing-masing anggota in-group menafsirkan ulang (reinterpretation) identitas sosial mereka. Keberhasilan pelabelan terlihat dari kemampuan pembaca untuk mengindentifikasi diri (selfdesignation) sesuai dengan definisi positif dari label tersebut. ${ }^{51}$ Dengan demikian, pelabelan dalam 1 Petrus 2:9-10 disebut strategi kreatifitas sosial (a strategy of social creativity $)^{52}$ untuk mempertahankan jati diri kelompok, yakni pengikut-pengikut Yesus Kristus di Asia Kecil. ${ }^{53}$

Deretan label tersebut efektif untuk menyadarkan kembali makna dan nilai identitas Kristen yang benar. Melalui gelar

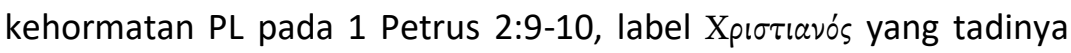
membuat mereka malu berubah nilai menjadi label kehormatan yang mendorong mereka untuk memuliakan Allah (4:16). Jadi, label kehormatan PL pada 1 Petrus 2:9-10 secara langsung meningkatkan

50. Trebilco menuliskan, "a label applied as an accusation, a cause for punishment and shame, is to be regarded as a badge of honor and pride." Trebilco, Self-designations and Group Identity in the New Testament, 284. Secara retoris, hal ini merupakan usaha maksimal rasul untuk meyakinkan pembaca bahwa mereka mempunyai identitas yang positif, bahkan mulia. Jobes, 1 Peter, 164.

51. Morissan, Psikologi Komunikasi (Bogor: Ghalia Indonesia, 2010), 110; Himes, A Foreknown Destiny for the Socially Destitute, 220;

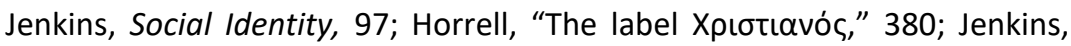
Social Identity, 98.

52. Trebilco, Self-designations and Group Identity in the New Testament, 285.

53. Jenkins, Social Identity, 100. 
harga diri pembacanya. Petrus ingin pembacanya merespons situasi yang mereka hadapi, tetapi dengan perspektif yang berbeda tentang jati diri mereka.

Jadi, berdasarkan nilai positif dari identitas virtual, pelabelan pada 1 Petrus 2:9-10 dinilai mampu untuk menaikkan harga diri pembaca. Peningkatan harga diri pembaca tidak dimaksudkan untuk membuat pembaca tinggi hati/sombong, melainkan mampu bertahan dalam kelompok Kristen, sekalipun kelompok tersebut minoritas dan inferior dalam lingkup sosialnya.

Identitas 1 Petrus 2:9-10 Menyatakan Vokasi Pembaca

Selain meningkatkan harga diri pembaca, deklarasi identitas dalam 1 Petrus 2:9-10 menjelaskan vokasi pembaca. Secara eksplisit, vokasi dari identitas tertuang pada frasa akhir di ayat 9. Petrus menandainya dengan kata ö $\pi \omega s$. Konjungsi subordinatif (in order that, supaya) ini diikuti oleh $\dot{\varepsilon}^{\xi} \xi \alpha \gamma \gamma \varepsilon \dot{i} \lambda \eta \tau \varepsilon$ sebagai verb subjunctive (memberitakan, menunjukkan). Penggunaan kata ö $\omega \varsigma$ ditambah dengan $\dot{\xi} \xi \alpha \gamma \gamma \varepsilon \dot{\imath} \lambda \eta \tau \varepsilon$ dalam bentuk subjunctive mengekspresikan makna tujuan lebih kuat daripada bentuk infinitive. ${ }^{54}$ Dengan lugas sang rasul mengatakan bahwa vokasi pembaca adalah memberitakan perbuatan-perbuatan Allah (LAI). Mereka menjadi agen pemberita

54. Moyise, Evoking Scripture: Seeing the Old Testament in the New, 89. 
perbuatan-perbuatan Allah kepada out-group. ${ }^{55}$ Motivasi utama orang Kristen diposisikan dalam dunia sosial adalah untuk tujuan misi. Oleh sebab itu, orientasi identitas bukan hanya menyangkut harga diri in-group, melainkan juga penjangkauan out-group. ${ }^{56}$

Kata tà "glorious deeds", "triumphs." Terjemahan-terjemahan ini berusaha mengungkapkan aspek-aspek yang mencakup kebajikan moral dari tindakan ilahi Allah. Semua kebaikan moral Allah harus diberitakan

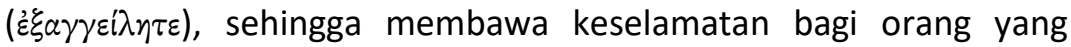
mengaku dan merespons apa yang dikerjakan Allah di dalam Yesus Kristus baik secara individu maupun kolekif. ${ }^{57}$ Dengan demikian, $\tau \dot{\alpha} \varsigma$

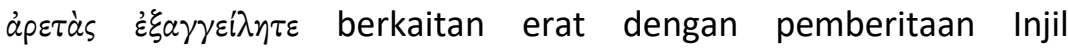
keselamatan (bdk. 1:25).

Deretan identitas juga menyatakan vokasi pembaca secara implisit. Sebagaimana sudah dijelaskan di atas, frasa $\beta a \sigma i ́ \lambda \varepsilon ı \nu$

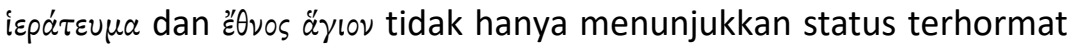
di hadapan Allah, tetapi menyiratkan tanggung jawab yang besar dalam menjalankan tugas di hadapan Allah. Mereka dijadikan kelompok terhormat supaya hidup terhormat dengan cara menjaga kekudusan hidup (1:15-16; 3:15; 4:4), berbuat baik kepada sesama

55. Duane F. Watson, "The Epistolary Rhetoric of 1 Peter, 2 Peter, and Jude" dalam Reading 1-2 Peter and Jude, ed. Eric F. Mason dan Troy W. Martin (Atlanta: Society of Biblical Literature, 2014), 53.

56. Boring, 1 Peter, 112.

57. Hillyer, Norman. 1 \& 2 Peter, Jude. UBCS (Grand Rapids: Baker Books, 1992), 69. 
$(2: 12,15,20 ; 3: 6,11,13,17,4: 19)$, dan melayani Tuhan $(2: 5 ; 4: 11)$ dalam seluruh eksistensi kehidupan mereka. Identitas sebagai orangorang yang terhormat sewajarnya memancarkan kebajikan moral Allah dari dalam diri mereka. Mereka harus menjadi saksi kebaikan Allah bagi dunia. Dengan demikian, vokasi pembaca dalam identitas tidak hanya mencakup pemberitaan Injil dari mulut saja, melainkan juga dari perilaku sehari-hari mereka. Vokasi pembaca juga berulang kali disampaikan dalam teks nasihat-nasihat surat (2:11-5:11) sebagai norma yang menggambarkan identitas in-group. Oleh karena itu, pemberitaan Injil dan tuntutan perilaku yang sesuai norma in-group adalah wujud vokasi yang terkandung dalam identitas 1 Petrus 2:910.

Identitas 1 Petrus 2:9-10 Menyatakan Nilai Pengharapan dalam Iman Dalam perspektif SIT, label memberikan evaluasi nilai kategori tertentu yang dimiliki oleh in-group. Sebagaimana dalam PL, identitas kehormatan Israel memberikan pengharapan untuk masa depan mereka, dalam konteks surat 1 Petrus, Petrus juga menyatakan pengharapan melalui deklarasi label PL. la berusaha meyakinkan pembaca mengenai pengharapan yang merupakan nilai positif dalam Kekristenan. ${ }^{58}$ Stigma out-group seolah menghilangkan nilai pengharapan dalam iman Kristen sehingga in-group malu

58. Bahkan menurut Carson, kutipan Hosea bukan hanya berfungsi menunjukkan new covenant, tetapi juga berfungsi sebagai mediator untuk belas kasihan Allah baik kepada orang Yahudi maupun bukan Yahudi (kafir). Carson, "1 Peter," 1032. 
menjadi Kristen. Oleh sebab itu, lima label PL dideklarasikan untuk memunculkan kembali nilai pengharapan yang ada dalam iman mereka $(1: 3,13,21 ; 3: 5,15)$.

Dari perikop 1:1-2:10, kata pengharapan muncul tiga kali, yakni pada 1:3, 1:13, dan 1:21 (lima kali dalam seluruh surat 1 Petrus [3:5 dan 3:15]). Kata pengharapan pada 1:3 ditulis $\dot{\varepsilon} \lambda \pi^{\prime} \hat{\delta} \alpha$ dengan bentuk noun accusative yang berarti "pengharapan." Kata pengharapan hadir dalam pujian kepada Allah ${ }^{59}$ dan disandingkan

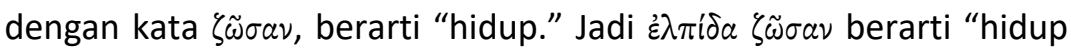
yang berpengharapan" (a living hope). Pengharapan bukan menjadi salah satu kualitas hidup dari jemaat, melainkan sebagai ukuran komprehensif untuk eksistensi jemaat (in-group). ${ }^{60}$ Hidup orang Kristen adalah hidup yang berpengharapan.

Pada 1:13, kata pengharapan ditulis dengan $\dot{\varepsilon} \lambda \pi i \sigma a \tau \varepsilon$ dalam bentuk imperative aorist yang berarti "berharaplah." Kata ini disandingkan dengan kata $\tau \varepsilon \lambda \varepsilon^{\prime} \omega \varsigma$ yang berarti "dengan penuh," "dengan lengkap." Jemaat dihimbau untuk berpengharapan penuh pada kasih karunia ( $\chi a ́ p ı s)$ yang membawa mereka ke dalam penyataan Yesus Kristus. Pengharapan dikaitkan langsung dengan kasih karunia. Definisi kasih karunia dijelaskan secara spesifik pada 2:20. la mengatakan bahwa jika konsekuensi perbuatan baik jemaat adalah penderitaan, hal tersebut adalah sebuah $\chi \alpha ́ p ı s$.

59. Douglas Harink, 1 \& 2 Peter. BTCB (Grand Rapids: Brazos, 2009), 42. 60. Harink, 1 \& 2 Peter, 54. 
Pada 1:21, kata pengharapan kembali dituliskan dengan bentuk noun $\left(\dot{\varepsilon} \lambda \pi^{i} \delta \alpha\right)$ dan ditulis dengan kata $\pi \dot{i} \sigma \tau \iota \nu$. Senada dengan dua bagian sebelumnya, $\dot{\varepsilon} \lambda \boldsymbol{i}^{\prime} \delta \alpha$ dalam ayat ini dikaitkan dengan kebangkitan Yesus Kristus dan iman kepada-Nya. Mereka dapat percaya kepada Yesus, karena Allah sendiri yang telah membangkitkan Yesus Kristus dari kematian. Maka secara implisit, mereka pun dapat berharap bahwa Allah juga akan membangkitkan mereka untuk hidup yang kekal dan memberi kemuliaan yang sama dalam kekekalan (5:10). ${ }^{61}$

Dari penjelasan ketiga teks mengenai pengharapan, maka dapat disimpulkan bahwa identitas dalam 1 Petrus 2:9-10 mengandung pengharapan eskatologis. Pengharapan muncul dari jaminan penyelamatan Allah yang sudah diterima jemaat. Jaminan ini membangkitkan pengharapan eskatologis jemaat untuk tetap berpegang pada iman mereka di dalam Yesus Kristus (1:13). Buah dari segala pengharapan orang percaya disebut sebagai $x \lambda \eta p o v o \mu i a v$, "warisan." 62 Pewaris dari $x \lambda$ novopiav adalah mereka yang sudah mengalami kelahiran baru di dalam Yesus Kristus (1:23).

Kata $x \lambda$ nрovouiav ini dijelaskan dengan tiga sifat, yakni abadi

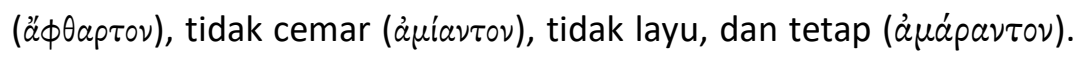
Warisan yang demikian tersimpan di sorga bagi mereka (1:4). Di satu sisi, hidup yang berpengharapan itu sudah diberikan kepada mereka,

61. Marshall, 1 Peter, 56.

62. Harink, 1 \& 2 Peter, 54. 
tetapi di sisi lain mereka masih menantikan (1:5) penggenapan sepenuhnya. Pengharapan eskatologis terus digemakan hingga akhir surat, yakni pada 5:10.

Akan tetapi pada perikop nasihat 3:1-7, pengharapan juga dikaitkan dalam konteks sosial pembaca. Sebagai perempuan kudus yang berpengharapan ( $\dot{\varepsilon} \lambda \pi i \zeta o v \sigma a l$, verb participle present) kepada Allah, para istri harus tunduk kepada suami. Artinya, pengharapan kepada Allah harus tetap dipegang dalam merespons tekanan sosial yang sedang dihadapi. Sebagaimana Marshall mengatakan labellabel PL menjelaskan kesesuaian pengalaman mereka dengan harapan mereka pada tingkat sosial dan spiritual. ${ }^{63}$

Dalam PL, identitas sebagai keturunan Abraham, Ishak, dan Yakub menjamin Israel untuk berharap bahwa Allah akan segera menyelamatkan mereka dari perbudakan (pengharapan sosial, bdk. Kel. 2:24; Kel. 19). Identitas sebagai umat Allah juga menjamin penyelamatan Israel sampai selama-lamanya (pengharapan eskatologis). Demikian pula jemaat 1 Petrus dapat berharap dan memercayai Allah sepenuhnya. Jemaat berharap untuk keselamatan yang tersedia di Sorga kelak, tetapi juga untuk pemulihan hidup mereka saat ini. Di satu sisi, pengharapan eskatologis dalam identitas kehormatan mendorong mereka bertahan dalam iman kepada Yesus sampai akhir. Di sisi lain, identitas kehormatan juga menjamin pengharapan sosial mereka di mana Allah akan segera membela dan

63. Marshall, 1 Peter, 24. 
melepaskan mereka dari tekanan out-group (bdk. 2:23, 3:12, 1516). ${ }^{64}$ Allah akan menghakimi mereka dengan adil $(1: 17 ; 2: 23 ; 4: 5$; 4:17). Jadi, identitas kehormatan pada 1 Petrus 2:9-10 memberikan pengharapan eskatologis dan sosial.

Menurut perspektif SIT, anggota in-group mampu memilih bertahan dalam kelompok yang inferior dan minoritas, karena ada nilai positif yang dipertahankan. Pengharapan yang diangkat Petrus adalah nilai evaluasi yang layak dipertimbangkan. Meskipun saat itu pembaca sedang mengalami banyak penderitaan, mereka masih bertahan karena ada pengharapan akan pemulihan hidup di dunia ini dan jaminan hidup kekal di Surga (1:17). Mereka hanya sementara saja menderita (5:10) dan akan selamanya hidup bahagia di Sorga (3:14). Perbandingan-perbandingan ini dibuat untuk menjadi pertimbangan kepada in-group. Status sebagai kelompok inferior dalam masyarakat tidak lantas menyurutkan iman mereka karena ada pengharapan yang menjadi nilai identitas Kristen.

Identitas 1 Petrus 2:9-10 Menyatukan Kohesi Anggota Jemaat

Signifikansi terakhir ini tidak ditemukan dalam konteks PL. Perbedaan etnis dapat menjadi faktor pemisah dalam in-group. Keberagaman identitas sosial lain dalam diri anggota (seperti budaya, status sosial, dan asosiasi) juga perlu diatasi. Selain itu, lokasi yang terpisah-pisah tidak boleh membuat komunitas mereka terpisah satu sama lain. Merespons kondisi demikian, Petrus berusaha

64. Bdk. Hillyer, 1 \& 2 Peter, Jude, 74. 
memperkuat kohesi jemaat. ${ }^{65}$ Oleh karena itu, identitas Israel dipakai untuk menyatukan seluruh jemaat dengan latar belakang yang berbeda.

Identitas PL tetap relevan dipakai, karena pada saat itu PL sudah diterima sebagai kitab suci orang Kristen yang berotoritas. ${ }^{66}$ Label kehormatan Israel sudah dipahami dan dapat diterima oleh ingroup. Semua anggota wajib mengakui otoritas $\mathrm{PL}$, sehingga mereka tidak perlu canggung dengan penggabungan label tersebut. Label Israel dipahami sebagai identitas religius Kristen. Meskipun label tersebut ditujukan kepada Israel dalam konteks aslinya, tidak ada eksklusivisme di dalam Kekristenan, sehingga tidak ada keberatan untuk menerima kelompok etnis bukan Yahudi sebagai anggota kelompok in-group. Petrus mempertahankan kelompok dengan cara menyatukan identitas sosial mereka. ${ }^{67}$

Penyatuan kohesi tampak dari konsistensi penggunaan echo

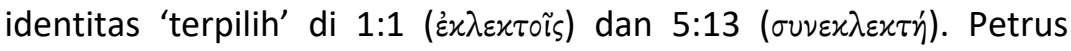
pertama kali menyapa pembacanya sebagai orang-orang terpilih. Namun di akhir surat, ia juga menyampaikan salam dari kelompok lain di luar lokal mereka sebagai $\sigma u v \varepsilon x \lambda \varepsilon x \tau o ́ s$ (kawan yang terpilih). ${ }^{68}$

65. Marshall, 1 Peter, 24.

66. Marshall, 1 Peter, 26.

67. Todd D. Still, dan Natalie R. Webb. "'Alien' among 'Pagans', 'Exiles' among 'Gentiles': Authorial Strategy and (Social) Identity in 1 Peter," dalam T \& T Clark Handbook to Social Identity in the New Testament, diedit oleh J. Brian Tucker dan Coleman A. Baker (London: Bloomsbury, 2014), 458.

68. Joel B. Green, 1 Peter (Grand Rapids: Eerdmans, 2007), 217; Witherington III, Letters and Homilies for Hellenized Christians, 245. 
Hal ini mengindikasikan bahwa orang Kristen tersebar di berbagai lokasi yang berbeda, tetapi tetap merupakan satu kelompok.

Penyatuan kohesi diperjelas dengan penggunakan kata $\Upsilon \mu \varepsilon \tilde{\varsigma}$ dalam 1 Petrus 2:9. Kata ini berarti 'kamu adalah ...' menyatakan

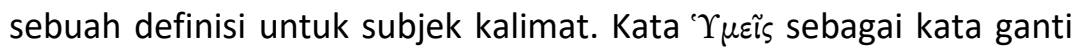
orang kedua bentuk jamak dipadankan dengan lima identitas yang ditulis dalam bentuk tunggal. Hal ini mengindikasikan bahwa label PL ditujukan kepada satu komunitas, yakni orang percaya, bukan pribadi. ${ }^{69}$ Semua pembaca tanpa pengecualian disatukan dalam satu

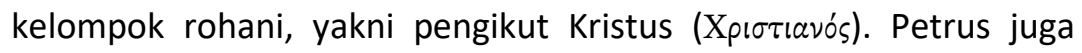

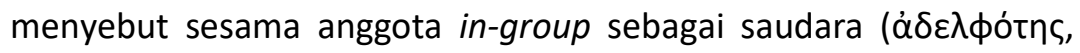
$2: 17)$ yang mendeskripsikan in-group adalah keluarga dalam relasi

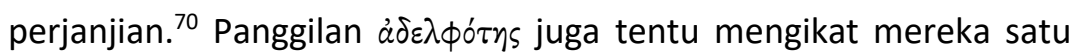
dengan yang lain semakin erat.

Selanjutnya, Petrus memberikan perintah untuk seia sekata

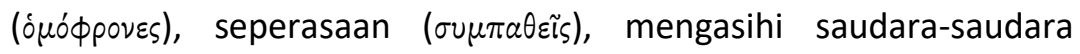

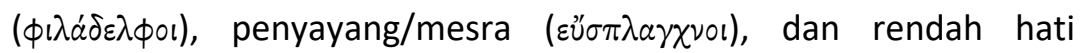

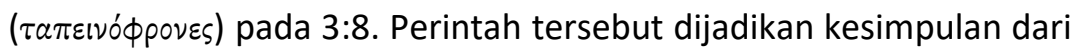
perintah-perintah sebelumnya yang ditandai dengan kata $\tau \dot{o} \delta \dot{\varepsilon} \tau \dot{\varepsilon} \lambda \circ \varsigma_{5}$ (dan akhirnya). Kelima perintah tersebut mendorong pembaca untuk

69. Elliott menuliskan, "They [labels] express not the qualities of individuals but rather the special nature of the community as a single cohesive unit with a common origin, character, and purpose." Elliott, 1 Peter, 444.

70. Hillyer, 1 \& 2 Peter, Jude, 82. 
menjalin hubungan harmonis dalam in-group. Keharmonisan satu dengan yang lain akan menciptakan kondisi yang kondusif dalam ingroup. ${ }^{71}$ Dengan demikian, Petrus menyadari bahwa penyatuan kohesi perlu dilakukan untuk mempersiapkan diri in-group sebelum merespons out-group. Label-label kehormatan Israel di 1 Petrus 2:910 menjadi puncak pembentukan identitas sosial pembaca yang mempersatukan in-group. Aspek iman kepada Yesus Kristus membuat mereka terhubung satu dengan yang lain dalam satu kelompok.

\section{Kesimpulan}

Penjabaran materi di atas mengungkapkan tentang pembentukan identitas pembaca yang terbukti kuat pada 1 Petrus 2:9-10. Melalui metodologi SIT telah dibuktikan bahwa pemberian label kehormatan Israel pada 1 Petrus 2:9-10 merupakan proses pelabelan untuk pembaca surat yang mengalami krisis identitas. Sebagai rasul, Petrus memberikan label kehormatan Israel untuk merespons situasi sosial pembaca. Signifikansi label tersebut, antara lain mengangkat derajat/harga diri pembacanya, menyatakan vokasi, memberikan pengharapan, dan menyatukan seluruh komunitas Kristen di Asia Kecil. Kehadiran gelar kehormatan Israel sebelum pemberian nasihat surat memberikan dorongan psikologis kepada pembaca untuk melakukan nasihat bukan hanya karena kesadaran identitas personal mereka, melainkan juga karena kesadaran 
identitas sosialnya bahwa mereka adalah bagian dari kelompok Kristen.

\section{Daftar Pustaka}

Achtemeier, Paul J. 1 Peter. Hermeneia. Minneapolis: Fortress, 1996.

Afif, Afthonul. Teori Identitas Sosial. Yogyakarta: UII, 2015.

Baron, Robert A. dan Donn Byrne. Psikologi Sosial. Edisi sepuluh. Jakarta: Erlangga, 2003.

Boring, M. Eugene. 1 Peter. Abingdon New Testament Commentaries. Nashville: Abingdon, 1999.

Bruce, F.F. Peter, Stephen, James \& John. Grand Rapids: Eermand, 1979.

Carson, D.A. "1 Peter." Dalam Commentary on the New Testament of the Old Testament, diedit oleh G.K. Beale dan D.A. Carson. Grand Rapids: Baker Academic, 2007.

Clarke, Andrew D. dan J. Brian Tucker. "Social History and Social Theory in the Study of Social Identity." Dalam T\&T Clark Handbook to Social Identity in the New Testament, diedit oleh J. Brian Tucker dan Coleman A. Baker. London: Bloomsbury, 2014.

Clowney, Edmund. The Message of 1 Peter. The Bible Speaks Today. Nottingham: InterVarsity, 1988.

Crowe, Brandon D. The Message of the General Epistles in the History of Redemption. New Jersey: P\&R Publishing, 2015.

Cote, James E. dan Charles G. Levine. Identity Formation, Agency and Culture: A Social Psycological Synthesis. New Jersey: Lawrence Erlbaum Associates, 2002.

Davids, Peter. A Theology of James, Peter and Jude. Diedit oleh Andreas Kostenberger. Grand Rapids: Zondervan, 2014.

Elliott, John H. Home for the Homeless. Philadelphia: Fortress, 1981.

Esler, Philip F. "An Outline of Social Identity Theory." Dalam T\&T Clark Handbook to Social Identity in the New Testament. London: Bloomsbury, 2016.

Feldmeier, Reinhard. The First Letter of Peter. Waco: Baylor University, 2008.

Ferguson, Everett. Backgrounds of Early Christianity. Edisi ketiga. Grand Rapids: Eermand, 2003. 
Forbes, Greg W. dan Jason J. F. Lim. 1 Peter. Farrer Road: Asia Theological Association, 2006.

Fretheim, Terence E. Exodus. Interpretation. Louisville: John Knox, 1991. Grudem, Wayne. 1 Peter. Grand Rapids: InterVarsity, 1988.

Guthrie, Donald. Pengantar Penjanjian Baru. Diterjemahkan oleh Hendry Ongkowidjojo. Volume 3. Surabaya: Momentum, 2009. Harink, Douglas. 1 \& 2 Peter. BTCB. Grand Rapids: Brazos, 2009.

Hillyer, Norman. 1 \& 2 Peter, Jude. UBCS. Grand Rapids: Baker Books, 1992.

Himes, Paul A. Foreknowledge and Social Identity in 1 Peter. Eugene: Pickwick Publications, 2014.

Houwelingen, P.H.R. Van. Surat 1 Petrus: Surat Edaran dari Babel. Diterjemahkan oleh Amsy Susilaradeya. Surabaya: Momentum, 2018.

Hubbard Jr., Robert L. dan Andrew Dearman. Introducing the Old Testament. Grand Rapids: Eerdmans, 2018.

Jenkins, Richard. Social Identity. Edisi keempat. Abingdon: Routledge, 2014.

Jobes, Karen H. 1 Peter. BECNT. Grand Rapids: Baker Academic, 2005.

Kee, Howard Clark. The Beginnings of Christianity. New York: T\&T Clark, 2005.

Kelly, J.N.D. A Commentary on the Epistle of Peter and Jude. Grand Rapids: Baker Book House, 1969.

Landy, Francis. Hosea. Edisi kedua. Sheffield: Sheffield Phoenix, 2011.

Lim, Kar Yong. Metaphor and Social Identity Formation in Paul's Letters to the Corinthians. Eugene: Pickwick Publishing, 2017.

Malherbe, Abraham J. Social Aspects of Early Christianity. Edisi kedua. Philadelphia: Fortress, 1983.

Marshall, I. Howard. 1 Peter. The IVP New Testament Commentary Series. Illinois: InterVarsity, 1991.

Martin, Judith N. dan Thomas K. Nakayama. Intercultural Communication in Contexts. Edisi keempat. New York: Mc Graw Hill, 2000.

McKnight, Scott. 1 Peter. The NIV Application Commentary. Grand Rapids: Zondervan, 1996.

Michaels, J. Ramsey. 1 Peter. WBC. Nashville: Thomas Nelson, 1988.

Morissan, Psikologi Komunikasi. Bogor: Ghalia Indonesia, 2010. 
Moyise, Steve. Evoking Scripture: Seeing the Old Testament in the New. New York: T\&T Clark, 2008.

Perkins, Pheme. First and Second Peter, James and Jude. Interpretation. Louisville: John Knox, 1995.

Schreiner, Thomas R. 1, 2 Peter, Jude. NAC. Nashville: Broadman \& Holman, 2003.

Smith, Gary V. Hosea, Amos, Micah. The NIV Application Commentary. Grand Rapids: Zondervan, 2001.

Still, Todd D. dan Natalie R. Webb. '“Alien' among 'Pagans', 'Exiles' among 'Gentiles': Authorial Strategy and (Social) Identity in 1 Peter." Dalam T\&T Clark Handbook to Social Identity in the New Testament, diedit oleh J. Brian Tucker dan Coleman A. Baker. London: Bloomsbury, 2014.

Taylor, Shelley E., Letitia Anne Peplau dan David O. Sears. Psikologi Sosial. Edisi dua belas. Jakarta: Kencana, 2009.

Trebilco, Paul. Self-designations and Group Identity in the New Testament. Cambridge: Cambridge University, 2014.

Tucker, J. Brian. You Belong to Christ: Paul and Formation of Social Identity in 1 Corinthians 1-4. Eugene: Pickwick Publications: 2010.

Watson, Duane F. "The Epistolary Rhetoric of 1 Peter, 2 Peter, and Jude." Dalam Reading 1-2 Peter and Jude, diedit oleh Eric F. Mason dan Troy W. Martin. Atlanta: Society of Biblical Literature, 2014.

Worchel, Stephen. "A Developmental View of the Search for Group Identity." Dalam Social Identity: International Perspectives, diedit oleh Stephen Worchel, J. Franscisco Morales, Dario Paez dan Jean-Claude Deschamps. London: Sage Publications, 1998.

Zvi, Ehud Ben. Hosea. Volume XXIA. Grand Rapids: Eerdmans, 2005.

\section{Jurnal}

Horrell, David G. "The label Xpıбııvós: 1 Peter 4:16 and the Formation of Christian Identity." JBL 126/2 (2007): 361-381. 